\title{
ATTITUDES OF EDUCATION AND REHABILITATION STUDENTS TOWARDS INDIVIDUALS WITH INTELLECTUAL DISABILITIES
}

\author{
MILENA NIKOLIĆ \\ Faculty for Special Education and Rehabilitation, Department of Special education and rehabilitation, \\ University of Tuzla, Tuzla, Bosnia and Herzegovina, contact: milena.nikolic@untz.ba
}

Received:14.12.2020.

Accepted: 18.04.2021.
Original research article

UDK: 316.644-057.875:376-056.36

doi: https://doi.org/10.31299/hrri.57.1.6

\begin{abstract}
The attitudes of education and rehabilitation students towards people with intellectual disabilities are very important, because they aim to be future professionals who will provide educational and rehabilitation treatment to these people, as well as advocates for their rights and needs. This study aimed to analyse the attitudes of students towards people with intellectual disabilities and to determine whether their attitudes differed based on self-assessments and sources of knowledge about intellectual disabilities, ways of getting to know a person with intellectual disabilities, and number of years of education. The study involved 100 students undergoing their first cycle of studies at the Faculty for Special Education and Rehabilitation, University of Tuzla. The Mental Retardation Attitude Inventory-Revised (MRAI-R) and a general questionnaire were used in this study. The results show that students express positive attitudes towards people with intellectual disabilities, they are positive about educational integration of these people, and respect their rights. They do not express to need to socially distance from them and do not attribute unfavourable characteristics to these people. There were no differences in attitudes based on self-assessments of knowledge and the sources of knowledge about intellectual disabilities, or the way in which they got to know a person with intellectual disabilities. There was a significant difference in attitudes based on the number of years of education: fourth-year students were observed to express the highest degree of positive attitudes towards people with intellectual disabilities globally and towards the integration of these people in society, and they expressed the lowest level of social distance. Given the small sample of research subjects, as well as the fact that the study involved students of one education and rehabilitation faculty. in Bosnia and Herzegovina, the results obtained and the conclusions derived from them should be considered with caution. Future research should include a larger sample of education and rehabilitation students to verify the results obtained in this study.
\end{abstract}

Keywords: attitudes, intellectual disabilities, students, education and rehabilitation

\section{INTRODUCTION}

The emergence of a social model of disability and the idea of inclusion has resulted in major changes in the way people with intellectual disabilities (ID) are cared for. The institutional model of care has been abandoned, and a system of care and support through the community has become increasingly prevalent. The functioning of people with ID is analysed through a bio-psycho-social model: here the functioning of a person in society is observed through the interaction of biological components (anatomical and physiological) of a person on the one hand and environmental factors on the other.
Antonak \& Livneh (1988; according to Tait \& Purdie, 2000) point out that people with disabilities operate within three social circles: the inner circle (relatives, friends, and peers), the central circle (rehabilitation professionals), and the outer circle (the general population). One of the key factors affecting the complete participation of people with ID in all three social circles is attitudes. Positive attitudes support the inclusion of these individuals in society, while negative attitudes hinder it (Findler, Vilchinsky, \& Werner, 2007). Given that inclusion in the wider community is the ultimate goal of educational and rehabilitation work carried out with people with ID, there is a strong interest 
in examining attitudes related to the outer circle or researching the attitudes of the general population towards people with ID.

Scior (2011) points out that the response of the general public to people with ID affects the likely success or failure of policies aimed at increasing their social inclusion. Morin, Rivard, Crocker, Boursier, \& Caron (2013) believe that understanding public attitudes toward people with ID can lead to the identification of factors that may hinder or facilitate the inclusion of such people, as well as the effectiveness of the services provided to them. It is therefore not surprising that research on the attitudes of the general population towards people with ID is the subject of a significant number of studies. However, although attitudes towards people with ID are the subject of a significant amount of research, it does not mean that this subject is fully understood. For example, Scior (2011) analysed 75 studies that dealt with the attitudes, beliefs, and awareness of the general population about ID and concluded that there is a lack of well-designed and comprehensive research on this subject because most of this research was conducted using small and unrepresentative samples. The author also noted the absence of well-designed evaluations aimed at reducing misconceptions and negative attitudes about ID. Research shows that the attitudes of the general population towards people with ID are generally positive (Morin et al., 2013; Nikolić, Mišić, \& Vantić-Tanjić, 2016), but they are somewhat more negative towards people with lower levels of functioning (Morin et al., 2013). People who perceive ID as milder disabilities show less social distance towards such individuals (Ouellette-Kuntz, Burge, Brown, \& Arsenaut, 2010).

Researchers are also interested in examining the attitudes of participants in the central circle, both current and future rehabilitation professionals. However, most research has focused on examining attitudes towards people with disabilities in general, and very little research is aimed at examining attitudes towards people with ID. There are several reasons why research into the attitudes of future rehabilitation professionals is important for the successful inclusion of people with disabilities in society. Apart from the fact that a future professional must be aware of his/her attitude towards people with disabilities (Antonak \& Livneh, 2000), it is important to develop positive attitudes during their studies (Tait \& Purdie, 2000). Besides, the attitude of these students are considered to be a precursor to the future attitudes of the society (Ćirović, 2011, according to Brojčin, Pavlović, Mastilo, \& Glumbić, 2015; Rathbone, 2013).

Typically, the subjects of such studies on attitudes towards people with disabilities are students of various profiles and many studies have addressed the attitudes of students of the so-called helping professions (health, education). However, there is very little research on the attitudes of education and rehabilitation students. This is surprising given the role that this group of experts have in the process of inclusion of people with disabilities in the society (Brojčin et al., 2015). Positive attitudes of educators and rehabilitators are important for the success of inclusion because they are specially trained to learn skills for successful work with people with disabilities; they are often seen as competent representatives of such people and are in a unique position to shape attitudes towards inclusive education (Brojčin, Banković, Glumbić, \& Kaljača, 2014). The attitudes of these experts have a positive effect on the attitudes of teachers who work with them (Brojčin et al., 2015). Also, they are involved in student behaviour, as well as social and emotional development (Mauceri, Di Marco, \& Licciardello, 2012)

Research on the attitudes of education and rehabilitation students towards people with disabilities shows that students express slightly positive attitudes towards these people (Brojčin et al., 2015), and that they feel somewhat comfortable interacting with them (Banković, Brojčin, \& Bakoč, 2019; Brojčin et al., 2015). Education and rehabilitation students generally have a high degree of compassion and a low degree of concern when they interact with people with disabilities, but when it comes to social contact, they find it more difficult to focus on the specific person (Brojčin et al., 2014). Interestingly, students of education and rehabilitation report that they have a low frequency of contact with people with disabilities (Brojčin et 
al., 2015) and that the frequency of contact does not affect the level of student discomfort (Banković et al., 2019). The lack of contact is surprising given that students need to be in direct contact with people with disabilities during practical classes. It is possible that when they analysed the social contact they had with people with disabilities, they did not take into account professional contact, but rather meant contact outside the study. Therefore, it is clear that such research should aim to specify what type of contact is being examined.

In this study, the subjects of the research on attitudes towards people with ID are students of education and rehabilitation. This is mainly because very often the attitudes of these students are taken for granted and it is expected a priori that they will be positive, which is not necessarily the case. Additionally, these students enroll themselves in this field of study for various reasons: very often they are only superficially acquainted with the population they will work with in the future, or they come from different high schools, and have different levels of prior knowledge on key subjects (psychology, sociology etc.).

Given the fact that research on the attitudes of students of educational and rehabilitation profiles towards people with disabilities is limited, especially research on attitudes towards people with ID, it is important to gain a better understanding of the attitudes of these students in order to promote inclusion.

\section{RESEARCH AIMS}

The aim of this study is to analyse the attitudes of education and rehabilitation students towards people with ID. An additional goal was to examine whether the attitude of these students differed based on self-assessments of knowledge, sources of knowledge about ID, way of getting to know a person with ID, and number of years of study.

\section{RESEARCH HYPOTHESES}

H1: The attitudes of education and rehabilitation students towards people with ID are positive.

$\mathrm{H} 2$ : The attitudes of education and rehabilitation students differ significantly based on self- assessments of knowledge and sources of knowledge about ID.

H3: The attitudes of education and rehabilitation students differ significantly based on the ways of getting to know a person with ID.

H4: The attitudes of education and rehabilitation students differ significantly based on the number of years of study.

\section{METHODS}

\section{Sample}

The sample consisted of 100 first cycle students from the Faculty for Special Education and Rehabilitation in the University of Tuzla. The sample was dominated by female students $(93 \%)$ and students of the special education and rehabilitation study program $(58 \%)$, followed by students of the logopaedics and audiology study program (27\%) and the behavioural disorders study program (15\%). First-year students from all three study programs (Special Education and Rehabilitation, Logopaedics and Audiology, Behavioural Disorders) accounted for $63 \%$ of the total sample; the rest of the sample included students in the second- (8\%), third- (12) \%), and fourth-year $(17 \%)$ of the Special Education and Rehabilitation study program. The sample was not uniform in terms of the number of years of study $\left(\chi^{2}=78.64, p=0.000\right)$.

Considering self-assessment of knowledge, $46 \%$ of the students believed that they had low levels of knowledge about people with ID, while $56 \%$ of them believed that they had high levels of knowledge. The results of a chi-square test $\left(\chi^{2}\right.$ $=0.640, p=0.424)$ showed that the sample was uniform in terms of the ranking of knowledge. This knowledge was based on personal experience in $30 \%$ of the students, or acquired in school $(39 \%)$, and through the media (31\%). The sample of students was uniform with respect to the question on where their knowledge on people with ID was based $\left(\chi^{2}=1.460, p=0.482\right)$. When it comes to getting to know a person with ID, $86 \%$ of students reported that they knew someone with ID, while only $14 \%$ of students said that they did not know a person with ID. Among the 
group of students who knew a person with ID, $18.6 \%(\mathrm{~N}=16)$ reported that this person was a friend or family member (formal relationship), while $81.4 \%(\mathrm{~N}=70)$ reported that it was an informal relationship with a person with ID from school, or their neighbourhood. The sample was not uniform with respect to the question on how they came to know a person with ID $\left(\chi^{2}=33.907\right.$, $\mathrm{p}=0.000)$.

\section{Instruments}

The attitude of students towards people with ID were assessed based on the Mental Retardation Attitude Inventory-Revised (MRAI-R; Antonak and Harth, 1994). The inventory contains 29 statements aimed at examining attitudes towards people with mental retardation or ID. The inventory is a four-point Likert type system, and the answers may be completely disagree (1), disagree (2), agree (3), or completely agree (4). The inventory contains both positive and negative statements and is constructed in such a way that a higher number of points indicates a more positive attitude towards people with ID. Negatively formed statements are scored in inversion. All statements are divided into four subscales.

The Integration-Segregation Subscale (INSE) measures attitudes towards integration into preschools, extracurricular programs, regular classes, neighbourhoods, and jobs. This subscale has seven statements: Integrating children who have ID and those who do not into the same preschool classes should not be attempted because of the turmoil it would cause; It is a good idea to have separate after-school programs for children who have ID and those who do not; School officials should not place children with ID and those without in the same classes; Assigning high school students who have ID and those who do not to the same classes is more trouble than it is worth; A child with ID should be integrated into regular classes in school; We should integrate people who have ID and those who do not into the same neighbourhoods; Having people who have ID and those who do not work at the same job sites will be beneficial to both.

The Private Rights Subscale (PRRT) measures attitudes towards the implementation of the human rights of people with ID and consists of the following seven statements: If I were a landlord, I would want to pick my tenants, even if this meant only renting to people who do not have ID; Regardless of his or her own views, a private nursery school director should be required to admit children with ID; Laws requiring employers not to discriminate against people with ID violate the rights of the individual who does not want to associate with people who are ID; Real estate agents should be required to show homes to families with children who have ID regardless of the desires of the homeowners; Campground and amusement park owners have the right to refuse to serve anyone they please, even if it means refusing people with ID; If I were a barber or beauty shop owner, I would not resent it if I were told that I had to serve people with ID; A person should not be permitted to run a day care centre if he or she will not serve children who have ID.

The Social Distance Subscale (SDIS) focuses on measuring attitudes/willingness to live close to people with ID and consists of the following eight statements: I would allow my child to accept an invitation to a birthday party for a child with ID; I am willing for my child to have children who have ID as close personal friends; I have no objection to attending movies or a play in the company of people with ID; I would rather not have people with ID as dinner guests with my friends who do not have ID; I would rather not have a person who has ID swim in the same pool that I swim in; I would be willing to introduce a person with ID to friends and neighbours in my home town; I would be willing to go to a competent barber or hairdresser with ID; I would rather not have people with ID live in the same apartment building that I live in.

The Subtle Derogatory Beliefs (SUDB) subscale is designed to determine the degree to which respondents attribute unfavourable characteristics to people with ID and consists of the following seven statements: People who have ID are not yet ready to practice the self-control that goes with social equality with people without ID; Even though children with ID are in public school, it is doubtful whether they will gain much from it; Although social mixing of people who have ID and who do not have ID may be right, it is impractical 
until people with ID learn to accept limits in their relations with the opposite sex; Children who have ID waste time playing in class instead of trying to do better; The problem of prejudice towards people with ID has been exaggerated; Even with equality of social opportunity, people with ID could not show themselves equal in social situations to people without ID; Even though people with ID have some cause for complaint, they would get what they want if they were more patient.

To facilitate the processing of the results, the mean result of the summary variable of the inventory was calculated to be 72.5 , while the mean result of the INSE, PRRT, and SUDB subscales was 17.5 , and that of the SDIS subscale was 20 . The Cronbach $\alpha$ coefficient of the research sample was 0.825 , which shows good internal consistency of the inventory.

A general questionnaire was used to obtain information about gender, years of education, study program, ranking of the level of knowledge on people with ID, ways in which this knowledge was acquired, and ways of getting to know people with ID.

\section{Procedure}

This study was conducted in the academic years 2019/2020. Students completed the questionnaires at the beginning of the lecture and were informed that participation was anonymous and not mandatory. Only students who gave their consent participated in the study.

The data were analysed using the statistical program, SPSS Statistics 25 (IBM). Differences in the attitudes of these students towards people with ID were tested using parametric and non-parametric statistical methods. Parametric statistical methods were used in subsamples that were uniform. Thus, a t-test was used to test differences in student attitudes towards self-assessment of knowledge about ID, while an analysis of variance was used to test for differences in sources of knowledge about ID. Differences in student attitudes between subsamples that were not uniform were tested using nonparametric statistical methods. Differences in student attitudes regarding the way of getting to know a person with ID were tested using the Mann-
Whitney U test, while differences in the number of years of education were tested using the KruskalWallis $\mathrm{H}$ test.

\section{RESULTS AND DISCUSSION}

Table 1. Attitudes of education and rehabilitation students based on the MRAI-R assessment

\begin{tabular}{|l|c|c|c|c|}
\hline & Min & Max & M & SD \\
\hline MRAI-R & 70.00 & 113.00 & 90.12 & 8.69 \\
\hline INSE & 13.00 & 28.00 & 21.25 & 3.22 \\
\hline SDIS & 19.00 & 32.00 & 28.17 & 2.86 \\
\hline SUDB & 13.00 & 26.00 & 18.42 & 2.48 \\
\hline PRRT & 17.00 & 28.00 & 22.33 & 2.33 \\
\hline
\end{tabular}

Legend: MRAI-R (Mental Retardation Attitude InventoryRevised); INSE (Integration-Segregation Subscale); SDIS (Social Distance Subscale); SUDB (Subtle Derogatory Beliefs Subscale); PRRT (Private Rights Subscale)

The education and rehabilitation students expressed positive attitudes towards people with ID as indicated by the arithmetic mean of the summary variable of the inventory, which was 90.12 (Table 1). The results show that these students expressed positive attitudes towards the integration of children with ID in regular preschool and school institutions (INSE, $\mathrm{M}=21.25$ ) and that they did not find it necessary to socially distance from people with ID (SDIS, $M=28.17$ ). They did not attribute unfavourable characteristics to people with ID (SUDB, $M=18.42$ ) and considered it important to respect the rights of these people (PRRT, $\mathrm{M}=22.33$ ).

These results confirm the first research hypothesis (H1: The attitudes of education and rehabilitation students towards people with ID are positive) and are expected considering that these are students who have chosen the profession of education-rehabilitation as their future vocation. Research on the attitudes of education and rehabilitation students towards people with ID, and even towards people with disabilities, has generally been conducted very rarely. Most previous research has been carried on populations of students from other profiles (health studies, teacher training colleges, etc.). Studies show that students from all profiles generally express moderately positive attitudes towards people with ID (MilačićVidojević, Glumbić, \& Kaljača, 2010, according to Cvijetić, 2010) and that students associated with certain groups in society (workers, pensioners, etc.) 
express significantly better attitudes towards people with ID (Yazbeck, McVilly, \& Parmenter, 2004). In one of the few studies examining the attitudes of future special educators and rehabilitators towards people with disabilities conducted by Brojčin et al. (2015), it was shown that students expressed slightly positive attitudes towards this population. A study of attitudes of students of different profiles towards people with disabilities in Saudi Arabia showed that students majoring in special education express the highest degree of positive attitudes towards people with disabilities (Haimour, 2012). Horner Johnson et al. (2002) studied a population of Japanese students and showed that the students who expressed an interest in working with people with disabilities in the future had more positive attitudes than students who did not show any such interests.

Although it is expected that education and rehabilitation students, compared to students from other profiles, will express the highest degree positive attitudes towards people with ID, this is not necessarily the case. A survey of attitudes towards people with ID conducted by Glumbić \& Ćirović (2011) at four faculties of the University of Belgrade (Orthodox Theological Faculty (OTF), Faculty of Special Education and Rehabilitation, Faculty of Philology and Faculty of Economics) showed that students of the Orthodox Theological Faculty had a more negative attitude towards eugenic interventions and a more positive attitude towards social inclusion of people with ID than other respondents. Their study went on to explain their results based on the fact that OTF students had adopted the concepts of Orthodox ontology and soteriology, and that human life in the Orthodox tradition is considered a gift from God. These results can serve as a warning that the attitudes of education and rehabilitation students should not be taken for granted nor should it be considered that these students will unconditionally be the most positive, and therefore, no work is required to promote and maintain their positive attitudes. Therefore, when attitudes are being studies, the tendency of the respondents to give socially desirable answers should always be taken into account and the results should always be considered with caution. At faculties for students of education and rehabilitation, it is necessary to plan the content in syllabuses in such a way that it encompasses all three components of attitude cognitive, emotional, and behavioural.

The results in Table 1 show that students express positive attitudes towards the integration of people with ID in regular preschool and school institutions, and that they are against the segregation of this population (INSE, $M=21.25$ ). Research generally shows that education and rehabilitation students show a positive attitude towards the integration/ inclusion of people with disabilities (Malak, 2013; Glumbić, Brojčin, \& Banković, 2010). However, Malak (2013) showed that while students express a high level of positive attitudes towards the inclusive education of people with physical, visual, and auditory impairments, their attitudes towards the inclusion of people with ID in regular classes were unfavourable. The attitudes of these students towards the inclusion of people with ID are not necessarily related to the attitudes of this population towards these people in general. Therefore, it is necessary to understand student attitudes towards inclusion of these people not only in regular educational institutions, but also in the wider community.

The results in Table 1 also show that education and rehabilitation students do not find it necessary to socially distance from people with ID (SDIS, M = 28.17). Previous research on this subject showed that students express a lower degree of social distance towards people with ID, but it has been observed that as questionnaire variables become more intimately connected to people with ID, social distances increase (Nikolić, Stijepić, \& Vantić-Tanjić, 2016). Therefore, it is important to conduct a study on social distance using an extensive questionnaire that can cover different social situations and degrees of contact. This would provide a more complete picture of student attitudes towards people with ID and their willingness to enter into social situations with these people outside a professional context.

These results also show that education and rehabilitation students do not attribute unfavourable characteristics to people with ID (SUDB, M $=18.42$ ) and believe that their rights should be respected (PRRT, $\mathrm{M}=22.33$; Table 1). Given that this study does not provide a qualitative analysis of the subscales, it would be useful to conduct further research on the opinions of education and rehabilitation students on the characteristics and rights of 
Table 2. Differences in attitudes of education and rehabilitation students towards people with ID based on selfassessments of knowledge about people with ID

\begin{tabular}{|c|c|c|c|c|c|c|}
\hline & Self-assessment of knowledge & $\mathbf{N}$ & M & SD & $\mathbf{t}$ & $\mathbf{p}$ \\
\hline \multirow[t]{2}{*}{ MRAI-R } & Low knowledge & 46 & 87.93 & 7.45 & \multirow[t]{2}{*}{-2.372} & \multirow[t]{2}{*}{0.092} \\
\hline & Higher knowledge & 54 & 91.98 & 9.30 & & \\
\hline \multirow[t]{2}{*}{ INSE } & Low knowledge & 46 & 20.61 & 2.85 & \multirow[t]{2}{*}{-1.861} & \multirow[t]{2}{*}{0.097} \\
\hline & Higher knowledge & 54 & 21.79 & 3.44 & & \\
\hline \multirow[t]{2}{*}{ SDIS } & Low knowledge & 46 & 27.37 & 2.69 & \multirow[t]{2}{*}{-2.661} & \multirow[t]{2}{*}{0.900} \\
\hline & Higher knowledge & 54 & 28.85 & 2.85 & & \\
\hline \multirow[t]{2}{*}{ SUDB } & Low knowledge & 46 & 18.11 & 2.12 & \multirow[t]{2}{*}{-1.159} & \multirow[t]{2}{*}{0.218} \\
\hline & Higher knowledge & 54 & 18.68 & 2.75 & & \\
\hline \multirow[t]{2}{*}{ PRRT } & Low knowledge & 46 & 21.91 & 2.24 & \multirow[t]{2}{*}{-1.665} & \multirow[t]{2}{*}{0.471} \\
\hline & Higher knowledge & 54 & 22.68 & 2.37 & & \\
\hline
\end{tabular}

Legend: MRAI-R (Mental Retardation Attitude Inventory-Revised); INSE (Integration-Segregation Subscale); SDIS (Social Distance Subscale); SUDB (Subtle Derogatory Beliefs Subscale); PRRT (Private Rights Subscale)

Table 3. Differences in the attitudes of education and rehabilitation students towards people with ID based on the source of knowledge about ID

\begin{tabular}{|c|c|c|c|c|c|c|}
\hline & Source of knowledge & $\mathbf{N}$ & $\mathbf{M}$ & SD & $\mathbf{F}$ & $\mathbf{p}$ \\
\hline \multirow[t]{3}{*}{ MRAI-R } & Personal experience & 30 & 91.77 & 9.86 & \multirow[t]{3}{*}{0.771} & \multirow[t]{3}{*}{0.465} \\
\hline & In school & 39 & 89.31 & 8.45 & & \\
\hline & Books or media & 31 & 89.55 & 7.83 & & \\
\hline \multirow[t]{3}{*}{ INSE } & Personal experience & 30 & 21.87 & 3.77 & \multirow[t]{3}{*}{0.900} & \multirow[t]{3}{*}{0.410} \\
\hline & In school & 39 & 20.82 & 3.09 & & \\
\hline & Books or media & 31 & 21.19 & 2.77 & & \\
\hline \multirow[t]{3}{*}{ SDIS } & Personal experience & 30 & 28.50 & 3.07 & \multirow[t]{3}{*}{0.500} & \multirow[t]{3}{*}{0.608} \\
\hline & In school & 39 & 28.23 & 2.93 & & \\
\hline & Books or media & 31 & 27.77 & 2.59 & & \\
\hline \multirow[t]{3}{*}{ SUDB } & Personal experience & 30 & 18.87 & 2.66 & \multirow[t]{3}{*}{0.706} & \multirow[t]{3}{*}{0.496} \\
\hline & In school & 39 & 18.18 & 2.57 & & \\
\hline & Books or media & 31 & 18.29 & 2.19 & & \\
\hline \multirow[t]{3}{*}{ PRRT } & Personal experience & 30 & 22.50 & 2.51 & \multirow[t]{3}{*}{0.758} & \multirow[t]{3}{*}{0.471} \\
\hline & In school & 39 & 21.97 & 2.41 & & \\
\hline & Books or media & 31 & 22.61 & 2.04 & & \\
\hline
\end{tabular}

Legend: MRAI-R (Mental Retardation Attitude Inventory-Revised); INSE (Integration-Segregation Subscale); SDIS (Social Distance Subscale); SUDB (Subtle Derogatory Beliefs Subscale); PRRT (Private Rights Subscale)

people with ID. Their opinions on these two issues are very important, not only because of their future work with these people, but also because as part of their professional work they will be, among other things, representatives of the rights and needs of these people in the wider community.

Students self-assessed the knowledge they have about ID by ranking their knowledge on a scale of 1 to 6 . To facilitate the processing of results, ranks 1 to 3 were considered to indicate low levels of knowledge, while ranks 4 to 6 were considered to indicate high levels of knowledge.
The results presented in Table 2 show that the attitudes of these students towards people with ID do not differ based on self-assessments of their knowledge about ID: the t-test results showed no statistical significant for the inventory summary variable or the subscales.

The results of the analysis of variance (Table 3) show that the attitudes of students towards people with ID did not differ based on the source of their knowledge about ID. No significant differences were observed in the summary variable or the subscales. 
Table 4. Differences in the attitudes of education and rehabilitation students towards people with ID based on the ways in which they got to know a person with ID

\begin{tabular}{|l|c|c|c|c|c|c|}
\hline How they got to know a person with ID & MRAI-R & INSE & SDIS & PRRT & SUDB \\
\hline \multirow{3}{*}{ Formal relationship } & $\mathrm{M}$ & 90.37 & 21.56 & 28.31 & 22.25 & 18,19 \\
\cline { 2 - 7 } & $\mathrm{N}$ & 16 & 16 & 16 & 16 & 16 \\
\cline { 2 - 7 } & $\mathrm{SD}$ & 7.36 & 2.73 & 2.24 & 2.21 & 2,53 \\
\hline Informal relationship & $\mathrm{M}$ & 90.58 & 21.36 & 28.38 & 22.48 & 18,44 \\
\cline { 2 - 7 } & $\mathrm{N}$ & 70 & 70 & 70 & 70 & 70 \\
\cline { 2 - 7 } & $\mathrm{SD}$ & 9.36 & 3.49 & 2.76 & 2.41 & 2,51 \\
\hline Mann-Whitney U & & 537,500 & 535.500 & 527.000 & 550.500 & 526.000 \\
\hline Wilcoxon W & 3022,500 & 3020.500 & 663.000 & 686.500 & 662.000 \\
\hline Z & $-0,250$ & -0.273 & -0.369 & -0.106 & -0.381 \\
\hline p & 0,803 & 0.785 & 0.712 & 0.915 & 0.703 \\
\hline
\end{tabular}

Legend: MRAI-R (Mental Retardation Attitude Inventory-Revised); INSE (Integration-Segregation Subscale); SDIS (Social Distance Subscale); SUDB (Subtle Derogatory Beliefs Subscale); PRRT (Private Rights Subscale)

Our results show that the attitudes of education and rehabilitation students towards people with ID did not differ based on the self-assessments or the sources of knowledge about ID. Therefore, Hypothesis 2 (The attitudes of education and rehabilitation students differ significantly based on self-assessments of knowledge and sources of knowledge about ID) was rejected. Previous studies have shown that knowledge of ID is not associated with the attitudes of students towards people with ID (Alnahdi, 2019; McManus, Feyes, \& Saucier, 2010). Alnahdi, Elhadi, \& Schwab (2020) reported that knowledge of ID is a predictor of positive attitudes among students. A significant number of studies on samples of students from different faculties show that education and information about people with disabilities can affect positive changes in the attitudes of students. Campbell, Gilmore, \& Cuskelly (2003) conducted research aimed at determining whether requiring students to explore one type of disability more thoroughly and participating in associated activities during their education could lead to changes not just in knowledge about a particular disability and attitudes toward inclusive education of these people, but also changes in attitudes towards disability in general. For example, considering Down syndrome was chosen as the disability to be studied further, previous research (Wishart \& Manning, 1996, according Campbell et al., 2003) found that students attending teacher training colleges had serious misconceptions about the condition, as well as the consequences it has on development. Attitudes were measured before and after the assignment, and the results showed that students positively changed not only their attitude towards people with Down syndrome and inclusive education, but also towards disability in general. Hickson (1995) investigated the formation and changes in attitudes towards people with disabilities based on a sample of Australian students from nursing and teacher training colleges. Both groups of students attended a mandatory course on disability, and as expected, this course had a positive impact on changing the attitudes of the students. Rice (2009) explored the attitudes of students towards people with ID after listening to either a lecture on special education or political science. Students who took a course in Introduction to special education had more positive attitudes toward people with ID than students who took a course in Political science. Hitch, Dell, \& Larkin (2016) surveyed attitudes toward people with disabilities among architecture students who were divided into two groups: one group consisted of students who were educated on the principles of universal design and the other group consisted of students who were not educated about universal design. Students who were educated on the principles of universal design had significantly lower levels of negative attitudes towards people with disabilities, and also expressed significantly less fear towards people with disabilities. Although a significant number of studies indicate a positive impact of education on student attitudes, Tait \& Purdie (2000) showed that attending a disability course for a year resulted in minimal changes in student attitudes. Therefore, education and information is only one way of changing student attitudes, indicating that the approach to changing student attitudes must be multidimensional. 
Differences in attitudes were also examined based on how the student got to know a person with ID. Of the total sample of 100 students, 86 knew a person with ID. Of the 86 who knew a person with ID, 16 studentss reported that it was a family member or a friend, which can be considered a formal relationship, while 70 of them reported that it was an acquaintance from school or their neighbourhood, which can be considered an informal relationship.

The Mann-Whitney U test results show that student attitudes towards people with ID did not differ based on the ways in which they got to know a person with ID; there were no significant differences in terms of the summary variable and the subscales. Therefore, Hypothesis 3 (The attitudes of education and rehabilitation students differ significantly based on the ways of getting to know a person with ID) was rejected.

These results were not expected since it was assumed that the nature of contact would affect attitudes and that students who had a more formal and personal contact with a person with ID would have a higher degree of positive attitudes. The reasons for such results may be the fact that the sample is a convenience sample and that out of a total of 86 students who knew a person with ID, only 16 stated that they had a formal relationship with these people. Therefore, these results must be validated with a larger sample of students, including students from other faculties in Bosnia and Herzegovina who attend study programs in education and rehabilitation. McManus et al. (2010) showed that the quality of contact can affect not only the positivity of student attitudes towards people with ID globally, but also more specifically the individual subscales. For example, it can also be related to the support received by people with ID to attend regular schools, be employed in the regular work environments, live in comfort, be in social proximity to their peers, expect their personal and social rights to be respected, and their positive characteristics to be recognized. Research shows that the existence of a person with ID in the family and having friends with ID significantly affects a student's perception of people with ID (Faraj, 2016), as well as attitudes towards these people (Alnahdi, 2019). Research generally shows that students who have more formal (personal) contact with people with disabilities have more positive attitudes towards these people (Hickson, 1995), as well as towards their inclusion in regular educational institutes (Malak, 2013); they also show lower levels of social distance towards them (Huskin, Reiser-Robbins, \& Kwon, 2018).

The results of the Kruskal-Wallis H test show that student attitudes towards people with ID are

Table 5. Differences in the attitudes of education and rehabilitation students towards people with ID based on the number of years of education

\begin{tabular}{|l|c|c|c|c|c|c|}
\hline Year of study & & MRAI-R & INSE & SDIS & PRRT & SUDB \\
\hline First-year & $\mathrm{M}$ & 88.48 & 20.68 & 27.49 & 22.05 & 18.43 \\
\cline { 2 - 7 } & $\mathrm{N}$ & 63 & 63 & 63 & 63 & 63 \\
\cline { 2 - 7 } & $\mathrm{SD}$ & 8.83 & 3.14 & 2.79 & 2.33 & 2.45 \\
\hline \multirow{4}{*}{ Second-year } & $\mathrm{M}$ & 89.50 & 20.50 & 27.75 & 22.12 & 19.12 \\
\cline { 2 - 7 } & $\mathrm{N}$ & 8 & 8 & 8 & 8 & 8 \\
\cline { 2 - 7 } & $\mathrm{SD}$ & 3.85 & 0.92 & 4.13 & 1.96 & 2.80 \\
\hline \multirow{5}{*}{ Third-year } & $\mathrm{M}$ & 91.92 & 21.83 & 29.58 & 23.42 & 17.25 \\
\cline { 2 - 7 } & $\mathrm{N}$ & 12 & 12 & 12 & 12 & 12 \\
\cline { 2 - 7 } & $\mathrm{SD}$ & 8.45 & 4.32 & 1.24 & 2.06 & 2.30 \\
\hline Fourth-year & $\mathrm{M}$ & 95.23 & 23.29 & 29.88 & 22.70 & 18.88 \\
\cline { 2 - 7 } & $\mathrm{N}$ & 17 & 17 & 17 & 17 & 17 \\
\cline { 2 - 7 } & $\mathrm{SD}$ & 8.32 & 2.57 & 2.34 & 2.57 & 2.50 \\
\hline Kruskal-Wallis H & & 8,429 & 9.797 & 14.433 & 4.209 & 3.057 \\
\hline $\mathrm{df}$ & & 3 & 3 & 3 & 3 & 3 \\
\hline $\mathrm{p}$ & & 0,038 & 0.020 & 0.002 & 0.240 & 0.383 \\
\hline
\end{tabular}

Legend: MRAI-R (Mental Retardation Attitude Inventory-Revised); INSE (Integration-Segregation Subscale); SDIS (Social Distance Subscale); SUDB (Subtle Derogatory Beliefs Subscale); PRRT (Private Rights Subscale) 
significantly different based on the number of years of education; the statistically significant variables are the summary variable of the questionnaire $(p=$ 0.038), subscale INSE - integration-segregation ( $p$ $=0.020)$, and the subscale SDIS - social distance $(p=0.002)$. The highest levels of positive attitudes based on the summary variable (AS $=95.23$ ) and the subscales $(\mathrm{INSE}=23.29$; $\mathrm{SODI}=29.88)$ were expressed by fourth-year students. Based on these results, Hypothesis 4 (The attitudes of education and rehabilitation students differ significantly based on the number of years of study) was accepted.

These results were expected, given that, compared to the other students, fourth-year students had more knowledge about ID and more experience in terms of contact with people with ID, which they gained through practical work. Brojčin et al. (2015) showed that the number of years of education does not affect the attitudes of future special educators and rehabilitators towards people with disabilities. The reason for the difference in the results of the present study and Brojčin et al. (2015) may be the fact that we specifically examined attitudes towards people with ID, and not disability in general. It is definitely important to study student attitudes towards people with other types of disabilities as well. Another reason may be the research sample, because in the present study involved mainly second-, third-, and fourth-year students from the Special Education and Rehabilitation study program, where there is a lot of content from the field of ID, especially in senior years (third and fourth year). The question arises as to what would happen if senior students of the Logopaedics and Audiology and Behavioural Disorders study programs were included in this study. Research on the attitudes of students from other faculties towards people with disabilities shows that the number of years of education affects the attitudes of students, and that the attitudes of the third- and fourth-year students are generally more positive compared to the first- and second-year students (Awoyera, 2011; Haimour, 2012).

\section{CONCLUSION}

The results of this study show that students of education and rehabilitation express positive attitudes towards people with ID. They are positive about the integration of these people in preschool and primary schools, and do not show any social distance towards these people. They do not attribute unfavourable characteristics to people with ID and feel that their rights should be respected.

The attitudes of education and rehabilitation students towards people with ID globally and based on subscales do not differ based on self-assessments of knowledge, sources of knowledge about ID, and ways in which they get to know a person with ID. In contrast, the attitudes of education and rehabilitation students towards people with ID differ based on the number of years of their education. Fourth-year students expressed the highest degree of positive attitudes towards people with ID globally, as well as towards the integration of these people in preschool and school institutions; they also showed the least extent of social distance from these people.

The results of this study and the conclusions that arise must be considered with reservations due to the limitations of the research. There is a need to conduct further research on the attitudes of students of all educational and rehabilitation profiles towards people with ID and to expand the sample of research to include students from other parts of Bosnia and Herzegovina. Furthermore, to get a more complete picture of the attitudes of students of education and rehabilitation towards people with ID, it is necessary to conduct research on their attitudes towards education and wider social inclusion of people with ID, explore their views on the social distancing of these people and on how to meet their rights and needs in society.

Although the results show that the attitudes of these students towards people with ID are positive, it does not mean that they should not be improved further. The syllabuses of their courses should include content that will positively influence the attitudes of students towards people with ID. The improvement of student attitudes should be based on a multidimensional approach in which programs aim to promote all three components of attitudes (cognitive, emotional, and behavioural), and this should be implemented in a planned and systematic manner. 


\section{REFERENCES}

Alnahdi, G. H. (2019). The interaction between knowledge and quality of contact to predict Saudi university students' attitudes toward people with intellectual disability. International Journal of Developmental Disabilities, 1-7. DOI: 10.1080/20473869.2019. 1638582

Alnahdi, G. H., Elhadi, A., \& Schwab, S. (2020). The positive impact of knowledge and quality of contact on university students' attitudes towards people with intellectual disability in the Arab world. Research in Developmental Disabilities, 106. https://doi.org/10.1016/j.ridd.2020.103765

Antonak, F. R., \& Livneh, H. (2000). Measurement of attitudes towards persons with disabilities. Disability and Rehabilitation, 22(5), 211-224. https://doi.org/10.1080/0963 82800296782

Antonak, R. F., \& Hart, R. (1994). Psychometric analysis and revision of the Mental Retardation Attitude Inventory. Mental Retardation, 32(4), 272-280.

Awoyera, O. (2011). Attitude of student nurses'toward people with disabilities. (Bachelor's Thesis, Abstract). Turku University of Applied Sciences, Turku.

Banković, S., Brojčin, B., \& Bakoč, A. (2019). Nivo ne(lagodnosti) budućih specijalnih edukatora u kontaktu sa osobama s ometenošću. Beogradska defektološka škola 25(3), 9-22.

Brojčin, B., Banković, S., Glumbić, N., \& Kaljača, S. (2014). Socijalna nelagodnost budućih defektologa u interakciji sa osobama sa ometenošću. U: M. Nikolić (ur.), Zbornik radova V međunarodne naučno-stručne konferencije Unapređenje kvaliteta života djece i mladih (str. 350-357). Tuzla: Udruženje za podršku i kreativni razvoj djece i mladih i Edukacijsko-rehabilitacijski fakultet Univerziteta u Tuzli.

Brojčin, B., Pavlović, A., Mastilo, B., \& Glumbić, N. (2015). Stavovi budućih specijalnih edukatora prema osobama s ometenošću. Nastava $i$ vaspitanje, 64(3), 489-505. DOI: 10.5937/ nasvas 1503489B

Campbell, J., Gilmore, L., \& Cuskelly, M. (2003). Changing student teachers' attitudes towards disability and inclusion. Journal of Intellectual \& Developmental Disability, 28(4), 369-379.

Cvijetić, M. (2018). Stavovi maturanata prema socijalnoj integraciji osoba sa intelektualnom ometenošću. Teme, XLII (1), 17-34. DOI: 10.22190/TEME1801017C

Faraj, R. K. (2016). Assessment of Undergraduate Nursing Students' Perception towards Mentally Disabled Child. Kufa Journal for Nursing Sciences, 6, 105-111.

Findler, L., Vilchinsky, N., \& Werner, S. (2007). The Multidimensional Attitudes Scale toward Persons with Disabilities (MAS): Construction and Validation. Rehabilitation Counseling Bulletin, 50(3), 166-176. DOI: $10.1177 / 00343552070500030401$

Glumbić, N., \& Ćirović, Lj. (2011). Stavovi budućih pravoslavnih teologa prema eugenici i socijalnoj inkluziji osoba sa intelektualnom ometenošcu. Specijalna edukacija i rehabilitacija (Beograd), 10(2), 237-247.

Glumbić, N., Brojčin, B., \& Banković, S. (2010). Stavovi studenata specijalne edukacije prema inkluzivnom obrazovanju. U: V. Đurek (ur.), Zbornik radova 8. kongresa s međunarodnim sudjelovanjem Uključivanje i podrška u zajednici (str. 121-132). Zagreb: Savez defektologa Hrvatske.

Haimour, A. I. (2012). Undergraduate universities student's attitudes toward disabled persons in Saudi Arabia. European Journal of Educational Studies, 4(2), 269-280.

Hickson, F. E. (1995). Attitude formation and change toward people with disabilities. (Doctoral Thesis). University of Sydney Faculty of Education, Sydney.

Hitch, D., Dell, K., \& Larkin, H. (2016). Does universal design education impact on the attitudes of architecture students towards people with disability? Journal of Accessibility and Design for All, 6(1), 26-48. DOI: 10.17411/ jacces.v6i1.103 
Horner Johnson, W., Keys, C., Henry, D., Yamaki, K., Oi, F., Watanabe, K., \& Fugjimura, I. (2002). Attitudes of Japanese students toward people with intellectual disability. Journal of Intellectual Disability Research, 46(5), 365-378. DOI: $10.1046 / j .1365-2788.2002 .00406 . x$

Huskin, P. R., Reiser-Robbins, C., \& Kwon, S. (2018). Attitudes of Undergraduate Students Toward Persons With Disabilities: Exploring Effects of Contact Experience on Social Distance Across Ten Disability Types. Rehabilitation Counseling Bulletin, 62(1), 53-63. DOI: 10.1177/0034355217727600

Malak, M. S. (2013). Inclusive Education in Bangladesh: Are Pre-service Teachers Ready to Accept Students with Special Educational Needs in Regular Classes? Disability, CBR and Inclusive Development, 24(1), 245-250. DOI: 10.5463/DCID.v24i1.191

Mauceri, M., Di Marco, G., \& Licciardello, O. (2012). Action Learning's effects on special educators' attitudes towards students. Procedia - Social and Behavioral Sciences, 46, 5698 - 5702. DOI: 10.1016/j.sbspro.2012.06.500

McManus, J. L., Feyes, K. J., \& Saucier, D. A. (2010). Contact and knowledge as predictors of attitudes toward individuals with intellectual disabilities. Journal of Social and Personal Relationships, 28(5), 579-590. DOI: $10.1177 / 0265407510385494$

Morin, D., Rivard, M., Crocker, A. G., Boursier, C. P., \& Caron, J. (2013). Public attitudes towards intellectual disability: a multidimensional perspective. Journal of Intellectual Disability Research, 57(3), 279-292. DOI: 10.1111/jir.12008

Nikolić, M., Mišić, M., \& Vantić-Tanjić, M. (2016). Stavovi i nivo socijalne distance prema osobama s intelektualnim teškoćama. U: M. Vantić-Tanjić i M. Nikolić, (ur.) Zbornik radova VII međunarodne naučno stručne konferencije Unapređenje kvalitete života djece i mladih (str. 405-418). Tuzla: Udruženje za podršku i kreativni razvoj djece i mladih i Edukacijsko-rehabilitacijski fakultet Univerziteta u Tuzli.

Nikolić, M., Stjepić, N., \& Vantić-Tanjić, M. (2016). Socijalna distanca studenata Edukacijsko-rehabilitacijskog fakulteta prema osobama s intelektualnim teškoćama. Defektologija, 22(1), 7-13.

Ouellette-Kuntz, H., Burge, P., Brown, H. K., \& Arsenaut, E. (2010). Public Attitudes towards Individuals with Intellectual Disabilities as Measured by the Concept of Social Distance. Journal of Applied Research in Intellectual Disabilities, 23, 132-142. DOI: 10.1111/j.1468-3148.2009.00514.x

Rathbone, L. (2013). An Analysis of Students Attitudes towards People with Disabilities. (BA Thesis). Dublin Business School Department of Psychology, Dublin.

Rice, C. J. (2009). Attitudes of undergraduate students toward people with intellectual disabilities: Consideration for future policy makers. College Student Journal, 43(1), 207-215.

Scior, K. (2011). Public awareness, attitudes and beliefs regarding intellectual disability: A systematic review. Research in Developmental Disabilities, 32, 2164-2182. DOI: 10.1016/j.ridd.2011.07.005

Tait, K., \& Purdie, N. (2000). Attitudes toward Disability: Teacher education for inclusive environments in an Australian university. International Journal of Disability, Development and Education, 47(1), 25-38. DOI:10.1080/103491200116110

Yazbeck, M., McVilly, K., \& Parmenter, T.R. (2004). Attitudes toward people with intellectual disability: An Australian perspective. Journal of Disability Policy Studies, 15, 97-111. 